University of Wollongong

Research Online

Faculty of Business - Papers (Archive)

Faculty of Business and Law

January 2016

Lending to private firms: evidence from China on the role of firm openness and bribery

Wenjuan Ruan

Murdoch University, wr807@uow.edu.au

Erwei Xiang

Edith Cowan University

Shiguang Ma

University of Wollongong, shiguang@uow.edu.au

Follow this and additional works at: https://ro.uow.edu.au/buspapers

Research Online is the open access institutional repository for the University of Wollongong. For further information contact the UOW Library: research-pubs@uow.edu.au 


\title{
Lending to private firms: evidence from China on the role of firm openness and bribery
}

\author{
Abstract \\ This paper investigates the effects of firm openness and bribery on bank lending decisions. Using World \\ Bank data covering 1869 private firms, we find evidence that paying bribes helps firms obtain bank credit \\ in China. But after adding firm openness into the analysis, the significance of the effect of bribery on \\ banking finance disappears. Instead, we find that banks in China prefer to allocate loans to firms with a \\ higher level of openness. This finding holds true only for large firms, manufacturing firms, and firms \\ located in regions with good banking development. We also find that private firms with greater \\ government assistance are more likely to obtain bank loans, and more credit overall.

\section{Publication Details} \\ Ruan, W., Xiang, E. \& Ma, S. (2016). Lending to private firms: evidence from China on the role of firm \\ openness and bribery. The 28th Annual Conference of the Chinese Economics Society Australia (CESA) \\ Chinese Economics Society Australia.
}


Lending to private firms: Evidence from China on the role of firm openness and bribery

\author{
Wenjuan Ruan \\ Murdoch University \\ WA 6150, Australia \\ Email: w.ruan@murdoch.edu.au \\ Erwei Xiang \\ Edith Cowan University \\ WA 6027, Australia \\ e.xiang@ecu.edu.au \\ Shiguang Ma \\ (Corresponding author) \\ University of Wollongong \\ NSW 2522, Australia. \\ Email: shiguang@uow.edu.au
}

\begin{abstract}
This paper investigates the effects of firm openness and bribery on bank lending decisions. Using World Bank data covering 1869 private firms, we find evidence that paying bribes helps firms obtain bank credit in China. But after adding firm openness into the analysis, the significance of the effect of bribery on banking finance disappears. Instead, we find that banks in China prefer to allocate loans to firms with a higher level of openness. This finding holds true only for large firms, manufacturing firms, and firms located in regions with good banking development. We also find that private firms with greater government assistance are more likely to obtain bank loans, and more credit overall.
\end{abstract}

Keywords: bank loan; bribery; firm openness; private firm

JEL Classification: D82; G21; G32; O17 


\section{Introduction}

China has a predominantly state-owned banking system, which features an enormous, underdeveloped banking sector controlled mainly by the largest state-owned banks. For a considerably long period, the main role of banks in China was to carry out policy lending following the government's instruction, rather than to operate in line with commercial considerations (Brandt and $\mathrm{Li}, 2003$ ). Consequently, the financial resources from the banking sector are mostly controlled by the government and used to support state-owned enterprises (SOEs), and the development of private sector has been hampered by limited access to banking finance (Bai et al., 2006; Dong et al., 2014). This paper aims to investigate the determinants affecting banks' lending decisions when allocating loans to private firms.

Corruption in the financial sector in China is not unusual. Pei (2008) and Chen et al. (2013) document the prevalence of bribes or kickbacks for loan approvals by banks over a lengthy period. Considering the superior bargaining power of banks in the borrowing-lending relationship, one might expect that in China, private firms paying bribes to bank officials more easily access banking finance and obtain more bank credit. However, Huang and Rice (2012) among others, argue that as China has been increasingly open and market-oriented, firm 'openness' becomes an important, yet poorly exploited factor in explaining some of financing behaviors.

The concept of firm openness was first introduced by Laursen and Salter (2003), which states that openness is a strategy for firms to search external sources of information. A 
firm's openness not only exhibits its enhanced engagement in inter-organizational networking and collaboration, such as knowledge exchange between firms and other economic agents like business partners and cooperated universities or research institutions (Laursen and Salter 2006, Economist Intelligence Unit, 2009; Zhang, 2009; Huang and Rice, 2012), but also increases information disclosure to outsiders, including banks.

In this paper, we use data from the World Bank to investigate the effects of firm bribery and firm openness on bank lending decisions towards private firms in China. Our sample consists of 1869 private Chinese firms, derived from the China: Investment Climate Survey 2003. We believe this dataset is suitable for the discussion of this paper since we aim to investigate that after China's entry to World Trade Organization in 2001, whether bank officials had concentrated on screening borrowers for quality or asking for bribes. The answer to this question can help to reflect the impacts of the market-oriented reform of the banking sector.

We find supportive evidence on the role of firm bribery in helping private firms obtain bank credit, when the effect of firm openness is ignored. However, once firm openness is considered, the significance of firm bribery disappears. Our baseline regression shows a positive relation between firm openness and banking finance, which is consistent with the notion that openness reduces information asymmetry. The effect is not only statistically significant but also economically relevant. For example, a one standard deviation increase in firm openness is associated with a 36.79 per cent increase in the size of banking finance relative to its sample mean. From sub-sample tests, we find that firm openness only improves access to banking finance for large firms, manufacturing firms and firms located 
in regions with good banking development. The results are robust to alternative measures of openness and bribery, different econometric specifications and considerations of endogeneity issues.

This study contributes to the literature in the following respects. We provide the first empirical evidence on the impact of firm openness on firms' bank debt. Among the studies exploring the bank-firm relationship, a literature stream documents the positive impact of bribery on firms' bank debt (e.g., Chen et al. (2013) and Fungáčová et al. (2015)). Compared with these studies, this paper further introduces the factor of firm openness in addition to bribery based on the notion that firms become more open by communicating with other firms and organizations and in the process release more information to lenders, and thus facilitates firms' bank borrowing.

The rest of the paper is organized as follows. In Section 2, we review the literature on the determinants of banks' lending decisions and develop our hypotheses. Section 3 discusses the sample processing and research design. We present key empirical findings in Section 4 and conclude in Section 5.

\section{Literature review and hypotheses development}

\subsection{Bribery and bank financing}

Focusing on country-level corruption, which is normally defined as the abuse of public office for private gain, several studies investigate the effect of corruption on bank credit but find mixed results. For example, Weill (2011) finds country-level corruption reduces bank credit and he attributes his finding to the reason that more corruption indicates a lower 
quality of the legal institutions that protect banks and enforce contracts. In contrast, Fan et al. (2012) document that firms in more corrupt countries tend to use more debt.

Apart from country-level corruption, corruption can also take place within the lending process through bribing bank officials to obtain bank loans (Fan et al., 2012; Beck et al., 2006). Regarding the firm-level relationship between bribery and bank debt, Fungáčová et al. (2015) find evidence that bribing bank officials facilitates firms' access to bank loans for a sample of firms in 14 transition countries. As for China, its banking system has long featured the dominance of state ownership in banks, and the main role of banks has been to lend to SOEs as per the government directive (Firth et al., 2009). With the reform of the banking sector since mid-1990s, banks were transformed from policy tools into real market entities. Brandt and Li (2003), however, identify the bank discrimination problem in China's financial market. Bank discrimination refers to the phenomenon of state-owned banks discriminating against private firms for non-profit reasons. In this institutional background, private firms are expected to pay bribes to bank officials and loan officers to obtain bank loans. In a recent study, Chen et al. (2013) provide empirical evidence that paying bribes contributes to an increase in a firm's bank debt in China.

Based on the abovementioned discussion, we propose the following hypothesis about the role of bribery in banks' allocation of loans:

H1.1: All else being equal, paying bribes to bank officials helps private firms get access to banking finance more easily and obtain more bank loans. 
Taking bribes, however, has potential consequences for bank officials (Wu, 2005). First, taking bribes exposes bank officials to substantial legal risks. Bank officials involved in taking bribes will bear the risk of legal actions, including prosecution, fines, or even jail sentences against them if the bribe-taking acts are caught. Second, bank officials taking bribes and allocating loans to firms lacking in quality will bring substantial financial risk for banks and thus block their path for promotion. More specifically, if a firm's manager resorts to bribery to obtain bank loans rather than show the firm's better products or services, innovation activities, investment projects, or competitiveness, bank officials could reasonably consider this firm as an unfavorable customer and refuse to provide it with a loan. Otherwise, the bank bears a potential financial risk of the firm defaulting. Bank officials that value their reputation and/or potential promotion opportunities would be more reluctant to bear this kind of risk. In addition, because most banks in China, and state-owned banks in particular, have no incentive or tradition of providing loans to private firms, bank officials might find bribes not to be worth the cost of their reputation and career.

Moreover, with the ongoing reform and commercialization of China's banking sector, especially after China's entry to the WTO, a stricter disciplinary system and performance-based incentive mechanism were introduced for bank executives and staff, encouraging them to manage risk and improve performance more effectively. For example, strict internal guidelines have been implied in the loan-making process. According to these guidelines, banks are required to separate the function of credit risk assessment from the loan management function. An important checks and balances system is also brought in to 
ensure an efficient and effective connection between these two functions (Chen et al., 2013).

Therefore, we contend that bank officials might not care about private firms' bribery due to their less incentive to take bribes and decreasing ability to intervene bank loan allocations. This leads to an alternative hypothesis regarding the bribery's role in bank loan allocation process:

H1.2: All else being equal, paying bribes to bank officials has no significant effect on getting access to banking finance or obtaining bank loans.

\subsection{Firm openness and bank financing}

Information asymmetries occur between the suppliers and recipients of finance where one party (finance recipients) has more, or better, information than the other (finance suppliers) does. Banks face substantial information asymmetry when screening qualified borrowers. The information gap between banks and firms would hamper the efficient allocation of financial resources, which may lead to either credit rating (Stiglitz and Weiss, 1981) or a wedge between lending and borrowing rates (King, 1986).

As Jõeveer (2013) argues, given the newness of financial markets and general opacity of business connections in transition and emerging countries, problems of asymmetric information are expected to be especially large. Public credit registry or private credit bureaus are seen as important sources of information for banks to screen eligible borrowers. However, in China the absence of these institutions exacerbated the problem of information asymmetry. Laursen and Salter (2003) introduce the concept of firm openness, which may 
influence banks' lending decision in the situation of information asymmetry. Fontana et al. (2003) extend the definition of openness as a knowledge-exchange process involving the combination of a searching strategy with a signaling activity. An important implication of Fontana et al. (2003)'s definition is that the signaling role of a firm's openness should be understood as an information-disclosing process by which firms inform the outside environment about the range of their competencies.

In the borrowing-lending scenario, research and practice show banks make lending decisions based on not only 'hard' quantitative criteria, such as balance sheets and income statement information, but also 'soft' qualitative information like ownership structure and the industry situation of borrowers (Berger and Udell, 2002; Yeung, 2009). Openness, acting as an important form of 'soft' qualitative information, could help substantially to alleviate the level of information asymmetry and to serve as a source of decision-related information for bank officials. The role of firm openness is important particularly when lending to the private sector, in which the information asymmetry is more severe (Firth et al., 2009). Based on the discussions above mentioned we propose the following hypothesis:

H2: All else being equal, the higher openness of a private firm is associated with greater access to bank financing and larger amount of bank loans.

\section{Sample and variables}

\subsection{The sample}

The data for this study is drawn mainly from the China: Investment Climate Survey 2003 conducted by the World Bank with support from the Enterprise Survey Organization of 
China's National Bureau of Statistics. The survey was conducted with 2400 responding firms belonging to 14 manufacturing and service sectors located in 18 cities across China. The survey includes firms with different legal statuses and ownership structures. Following Firth et al. (2009), we identify a firm as 'private' if the private sector owns more than 50 per cent of its shares. According to this condition, there are 1869 private firms in our sample. To eliminate the possible effects of outliers, all variables are winsorized at the $1^{\text {st }}$ and $99^{\text {th }}$ percentiles.

\subsection{Variables}

\subsubsection{Bank financing}

Specifically, we use two measures to capture bank financing with one concerning access to bank loans and the other quantifying the amount of banking finance. These measures are based on two key questions in the survey China: Investment Climate Survey 2003. We code the response to the first question 'Do you have a loan from a bank or financial institution?' as 1 if the firm's response is 'Yes' and 0 for 'No'. This is denoted as access to bank financing. The second question asks 'What is the amount of the line of credit'? We scale this response by the firm's total assets to derive the variable 'size of banking finance'.

\subsubsection{Bribery}

As both paying and taking bribes are illegal in China, there is no direct or observable data from the dataset on whether private firms actually paid bribes to bank officials for obtaining bank loans. Instead, we follow Cai et al. (2011) and Chen et al. (2013), and use the amount of entertainment and travel costs (ETC) scaled by sales as the proxy for bribery. 
In Chinese firm accounting books, ETC is a standard expenditure item and is used supposedly for reimbursing normal business expenses required by firms in their normal operations. However, in practice, ETC not only includes expenses for legitimate travel and other expenses, but also covers expenditures used commonly to bribe government or bank officials, clients, and suppliers, or simply to account for implicit CEO pay and managerial excesses.

Empirically, we generate the value of ETC based on the answer to the key question in the China: Investment Climate Survey 2003 that takes the following form: 'What are the total travel and entertainment costs spent in 2002 by the firm?' and ultimately scale the ETC by sales to proxy for the bribe payments to bank officials. In the robustness test, we also construct an alternative measure of bribe payments to banks and include it in the regression analysis (see the robustness test for details).

\subsubsection{Firm openness}

Following Laursen and Salter (2006), Zhang (2009) and Huang and Rice (2012), we proxy for 'firm openness' in a broader perspective based on the responses relating to whether or not the firm had engaged in any contractual or long-standing relationship with universities, research institutions, or other firm. Firm openness is assigned values between 0 and 3 . The value of 0 is used for no relationship with any of the three kinds of organization, 1 when the relationship is with any one of the three kinds of organization, 2 when the relationship is with any two of the three kinds of organization and 3 when the relationship is with all three kinds of organizations. 


\subsubsection{Control variables}

Firth et al. (2009) find that Chinese banks extend loans to financially healthier firms. Following Firth et al. (2009), we use a one-year lagged return on sales (ROS) to measure firm performance, which is calculated using the one-year lagged earnings before interest and taxes divided by total sales. Research agrees that political connection is a valuable asset that may have a favorable effect on bank lending decisions (Dinc, 2005; Faccio et al., 2006). In this paper, we use government help (Govt help) to measure political connection, which is a dummy variable if a firm's answer to the question 'During the year 2002, did any government agency or official assist you in obtaining bank financing?' is 'Yes', and 0 otherwise.

Firth et al. (2009) find that banks tend to allocate loans to better-governed firms. In contrast, Yao et al. (2010) find a limited impact of the corporate governance mechanism in borrowers on banks' lending decisions. In this paper, we use a group of corporate governance variables to assess the effect of corporate governance of private firms on obtaining banking finance. Specifically, manager experience is the number of years the general manager has held his or her position at the current firm, and manager tenure is the tenure of the general manager. Managerial ownership is a dummy variable that equals 1 if the general manager's answer to the question of 'Does the general manager own company stocks?' is 'Yes', and 0 otherwise. Manager wage payment is a dummy variable that equals 1 if the general manager's wage is paid annually and 0 otherwise. Manager incentive is a dummy variable that takes the value of 1 if the general manager's answer to the question 'Does the general manager have any incentive plans linking his or her income to firm 
performance?' is 'Yes', and 0 otherwise. Board ownership is the percentage of board directors that own shares in the firm. Board size is the number of board directors, and board independence is the percentage of independent directors among the total board directors. Duality is a dummy variable that equals 1 if the general manager is also the chair of the board, and 0 otherwise.

This paper also controls some other possible factors. Firm size is measured as the natural logarithm of firm total assets, and firm age is the natural logarithm of the number of years since the firm was established. Following Barth et al. (2009), we also include the variable named 'bank competition' to control for the reduced bargaining power of bank officials in a competitive market. Bank competition is defined as the natural logarithm of the number of banks with which a firm does business. Following Dopuch and Simiunic (1982) and Barth et al. (2009), we include a dummy variable (Audit) to measure the accuracy and reliability of firms' financial statements. This variable equals 1 if the answer to the question 'Was company financial statement audited every year?' is 'Yes', and 0 otherwise. Since Svensson (2005) finds that higher GDP per capita is related to less corruption, we include the variable 'GDP per capita'. Since the dataset that we use includes 2400 responding firms located in 18 cities, the city-level GDP per capita is used, which is the natural logarithm of gross national product per capita in each city where each firm locates. City population is the natural logarithm of population of the city in which the firm is located. As Li et al. (2009) and Firth et al. (2009) find that marketization ${ }^{1}$ is an

\footnotetext{
${ }^{1}$ Fan et al. (2012) develop a marketization index as the measurement of the regional economic development and institutional efficiency. Higher scores on the index indicate a relatively high level of economic development and institutional efficiency. Banking sector marketization is an index measuring the extent of banking sector development for different regions (provinces), which is one of the dimensions of the marketization index.
} 
important determinant of firms' debt financing constitution in China, we use Fan et al. (2012)'s banking sector marketization to measure the institutional environment. The influence of industries is also considered by including industry dummy variables in the regressions. Since region fixed effects can absorb variations related to location, we also include city fixed effects in the regressions and cluster the standard errors on city level.

Table 1 describes the summary statistics of the variables in this study. Only 21.51 per cent of sample firms obtain loans from banks, and the proportion of bank loans to assets is 4.8 per cent on average. Bribery, proxied for by ETC scaled by sales, has a mean of 2.42 per cent and a median of 1.04 per cent. On average, more than half of the sample firms demonstrate strong financial performance. In an unreported result, we also check the correlations between all of the variables and find that most of the correlation coefficients are below 0.3 (for example, the correlation coefficient between bribery measure and openness measure is just 0.0289 ), revealing that multicollinearity is not a serious problem in this study.

\section{[Insert Table 1 here]}

Table 2 presents the univariate tests of the dependent variables based on different classifications of the sample. 'Difference tests' columns in Panel A, B and C report the $t$ value for the $T$-test and the $z$ value for the Wilcoxon test of differences in mean and median. Panel A reports the univariate test for firms with different levels of openness. 'Openness_0' refers to firms having no relationship with any local university, research institution, or other firms; 'Openness_1', 'Openness_2' and 'Openness_3' refer to firms 
having a relationship with any one, two, and all three of the three kinds of organization, respectively. This panel shows that increased firm openness increases the likelihood of obtaining banking finance, while greater firm openness assists borrowers in obtaining more bank credit.

Panel B presents the univariate test for firms with and without bribe payments. 'Non-bribery' and 'Bribery' refer to firms without and with bribe payments, respectively. The results suggest that paying bribes does help private firms with their banking finance, and provides preliminary support for Hypothesis 1.1 . We test this relation in a multivariate framework in the following section.

Panel $\mathrm{C}$ presents the univariate test for firms with low and high bribe payments. 'Low-bribery' and 'High-bribery' refer to firms with low bribe payments (below the median) and high bribe payments (above the median), respectively. Interestingly, this panel indicates that compared with private firms that pay high bribes, those paying low bribes get larger access to bank financing and obtain more bank loans. This result is discussed in Section 4.4.3.

\section{[Insert Table 2 here]}

\section{Empirical results}

\subsection{The effect of private firm's bribery on its bank financing}

To explore the impact of firm bribery on bank financing, we model a bank official's latent response as follows: 


\section{Bank financing $_{i}$}

$$
\begin{aligned}
& =\beta_{0}+\beta_{1} \text { Financial performance }_{i}+\beta_{2} \text { Bribery }_{i}+\beta_{3} \text { Political connection }_{i} \\
& +\beta_{4} \text { Corporate governance }_{i}+\beta_{5} \text { Other controls }_{i}+\beta_{6} \text { Industry }_{i}+\varepsilon_{i}(1)
\end{aligned}
$$

where the subscript $i$ indicates a firm. As defined in Section 3.2.1, the dependent variable bank financing measures a firm's access to banking finance and the amount of the loan granted by the banks. We use Logit models for specifications where access to bank finance is the dependent variable, and ordinary least squares (OLS) models for those where the size of the bank loan is the dependent variable. The results of the effect of private firm's bribery on its bank financing are shown in Table 3. We first run the regressions that include 'standard' determinants of bank credit like firm profitability, size, age, bank competition and proxies for the macroeconomic environment including GDP per capita, city population and development of banking sector (see Column (1) and (2)). A set of corporate governance measures (see Column (3) and (4)) and bribery (see Column (5) and (6)) are added to the estimations subsequently.

\section{[Insert Table 3 here]}

As seen in Column (1) and (2), firm performance measured by lagged ROS is positively and significantly associated with both access to and size of banking finance. This result is consistent with that of Firth et al. (2009), who argue that banks tend to allocate loans to financially healthier firms. When we add corporate governance measures into the estimations (see Column (3) and (4), Table 3), firm performance is positively related to access to banking finance and size of banking finance at 10 and 1 per cent level, respectively. But there is no consistently significant relation between bank debt measures 
and governance measures. Then we add firm bribery into the analysis. As shown in Column (6), bribery is found to be positively and significantly related to size of banking finance. This result suggests that bribery plays a positive effect on helping private firms obtain more bank loans.

Table 3 also shows that whether the firm's financial statement was audited every year does not show a significantly positive relationship with bank financing, indicating that banks might not pay much attention to auditing. A positive and statistically significant relationship is found between government help and private firms' bank financing. This reveals that political connection is an important factor for private firms in accessing bank financing, which is consistent with Firth et al. (2009). No significant relationship between bank competition and bank financing is found, which is inconsistent with the findings of Barth et al. (2009). This result may be due to the situation that China's predominantly state-owned banking sector features substantial discrimination towards private firms. The coefficient of firm size is positive and statistically significant at the 1 per cent level, revealing that larger firms are more likely to obtain bank loans.

\subsection{The effect of private firm's openness on its bank financing}

Compared to the work done in Firth et al. (2009) and Chen et al. (2013), which examines the effect of firm performance and bribery on bank's lending decisions, this paper further investigates the effect of firm openness on bank's lending to private firms. Thus we construct the following model: 


\section{Bank financing $_{i}$}

$$
\begin{aligned}
& =\beta_{0}+\beta_{1} \text { Financial performance }_{\mathrm{i}}+\beta_{2} \text { Bribery }_{\mathrm{i}}+\beta_{3} \text { Openness }_{\mathrm{i}} \\
& +\beta_{4} \text { Bribery }_{\mathrm{i}} \times \text { Openness }_{\mathrm{i}}+\beta_{5} \text { Political connection }_{\mathrm{i}} \\
& +\beta_{6} \text { Corporate governance }_{\mathrm{i}}+\beta_{7} \text { Other controls }_{\mathrm{i}}+\beta_{8} \text { Industry }_{\mathrm{i}}+\varepsilon_{\mathrm{i}}(2)
\end{aligned}
$$

where the subscript $i$ indicates a firm. The dependent variable bank financing measures a firm's access to banking finance and the amount of the loan granted by the banks. Compared with Equation (1), firm openness is added as one of the independent variables. We use Logit models for specifications where access to bank finance is the dependent variable, and OLS models for those where the size of the bank loan is the dependent variable. The empirical results are shown in Table $\mathbf{4}^{2}$.

\section{[Insert Table 4 here]}

When considering the potential effect of firm openness, compared to that in Table 3, neither ROS nor bribery is significantly related to firm's access to banking finance (see Column (1), Table 4). But our variable of interest, firm openness, shows a significantly positive effect on firm's access to banking finance. This result suggests that increased firm openness results in a greater likelihood of a firm obtaining banking finance, even after controlling for firm performance, bribery and other possible determinants. For the interaction term between bribery and openness, the insignificant coefficient indicates that the interaction effect between bribery and openness on a firm's bank financing is not strong.

\footnotetext{
${ }^{2}$ To reduce the space taken for tables, we only report the important coefficients in Table 4-7.
} 
In Column (2) of Table 4, ROS is significant but bribery is insignificant when firm openness is included. The coefficient of openness is 0.0219 , which is positive and significant at the 1 per cent level, indicating that firm openness could reduce the level of information asymmetry encountered by banks and reassure them to grant more loans. The effect is not only statistically significant but also economically relevant. For example, a one standard deviation increase in firm openness is associated with a 36.79 per cent increase in the size of banking finance relative to its sample mean.

To conclude, the effect of paying bribes on obtaining bank loans disappears once the firm openness factor is considered, which indicates the relationship between bribery and bank financing found in Chen et al. (2013) might be absorbed by firm openness. In other words, bank officials are more informed by firm openness instead of bribe payments from firms when making lending decisions. Therefore, after considering firm openness, Hypothesis 1.1 is no longer supported, while Hypothesis 1.2 and Hypothesis 2 are supported.

\subsection{Sub-sample tests}

Theoretically, small firms are less transparent, which makes the information asymmetry issue more severe when bank officials are dealing with these firms. Therefore, banks may prefer large firms, which are typically more open and thus have more information sources available for the bank to know about the firm. Our results in Table 3 and Table 4 provide supportive evidence that banks allocate more credit to large firms. To take a closer look at the role of firm size in helping firms obtain bank loans, we split our entire sample into two 
sub-samples by firm size following Firth et al. (2009). Specifically, a firm is categorized as a large (small) firm if its size is above (below) the sample median. The results are presented in Table 5.

\section{[Insert Table 5 here]}

Firm openness does not show a significant association with both access to banking finance and size of banking finance in small firms (see Column (1) and (2), Table 5). However, openness is related positively and significantly to bank financing, regardless of which bank financing measure is used in large firms (see Column (3) and (4), Table 5). The results suggest that openness is a more important determinant for large firms than for small firms in banks' lending decisions. This might be partly because small firms usually have fewer opportunities to show their openness. In other words, it is difficult for small firms to enter into contractual or long-term relationships with other firms, universities, or research institutes. In both small and large firms, we find no evidence supporting bribery's role in helping private firms obtain bank credits when firm openness is included.

Firms operating in different industries might be subject to different industry conditions, such as industry regulations, market competition, external financial dependence, and level of information asymmetry (Rajan and Zingales, 1998). Thus, we include a set of industry dummies to control for the variation among industries in Tables 3 and Table 4. Considering that our sample size is not large and the sample firms are not distributed equally, this might bias the results. Therefore, we divide the entire sample into two groups according to firms' industry. Specifically, accounting and the non-banking financial 
services, advertisement and marketing, and business services are reclassified as 'service industry', while other sectors are reclassified as 'manufacturing industry'. The regression results are shown in Table 6.

\section{[Insert Table 6 here]}

For manufacturing firms only, openness displays a positive and significant effect on size of banking finance (see Column (2), Table 6). The lack of significance of relationship between openness and bank financing for firms in the service industry might be attributed to the lesser need for these firms to build long-term or contractual relationships with other organizations. Again, we do not find supportive evidence on the role of bribery in helping firms obtain banking finance when firm openness is inclusive.

Institutional environment is found to have a substantial effect on firms' operations (e.g., Firth et al., 2009). Chen et al. (2006) argue that an outstanding feature of China's economy is the imbalance in terms of the development of banking sector, in particular in different regions. Locations with better banking sector development can be expected to provide more opportunities for firms to acquire bank loans. To investigate the influence of banking sector marketization on firms' bank financing further, we split the entire sample into a poor banking development group and a good banking development group. Specifically, firms are classified in the good (or poor) banking development group if the value of banking sector marketization for their location is above (or below) the sample median. The results are presented in Table 7.

\section{[Insert Table 7 here]}


As in Table 7, openness is found to have a positive and significant effect on firms' bank financing only for firms located in regions with higher banking sector marketization. This result implies that in areas with a developed banking sector, banks have more incentive and skills to capture information about potential borrowers, including the information released through firms' communications and collaborations with other organizations. Similarly, in these regions, bribery is found to have no significant effect on firms' bank financing.

\subsection{Robustness tests ${ }^{3}$}

\subsubsection{Alternative measures for bribery}

In the main test, we follow Cai et al. (2011) and Chen et al. (2013) and use the amount of ETC scaled by sales as the proxy for bribery. Given the fact that the amount of loan is scaled by total assets as one of dependent variables, we also conduct the robustness test by scaling bribes using total assets. Our results are robust in this case.

In addition, similar to Beck et al. (2007) and Barth et al. (2009)'s work, we construct a measure of bribe payments based on the key question in relation to firms' bribe payments. The question takes the following form: 'In your dealings with bank officials and loan officers, was a gift or informal payment expected?' We include a dummy that equals 1 if the respondent's answer is 'Yes', and 0 otherwise, to measure firms' bribe payments to bank officials. The empirical results are consistent with our main results.

\footnotetext{
${ }^{3}$ For brevity, the results of robustness tests are not presented but available upon request.
} 


\subsubsection{Alternative measures for openness}

In our paper, contractual or long-standing relationship with a university, research institution or other firms is used to proxy for firm openness. But most firms could have many kinds of connection with other firms as long as they operate, such as suppliers. To ensure our results are not driven by alternative measures of openness, we perform a robustness test by using the relationship with suppliers (the natural logarithm of the total number of suppliers of the key raw materials and/or the key service bought from) as a measure of firm openness. The results show that the alternative proxy of openness is positively associated with banking finance (measured by 'size of banking finance').

In addition, Ricci and Trionfetti (2012) find if firms benefit from foreign networks (ownership and financial linkages), domestic networks (chamber of commerce, links to regulation), or communication networks (E-mail, internet), they are more likely to export, which to some extent reflect these firms are more 'open'. Following Ricci and Trionfetti (2012), we use 'foreign participation' (measured by the percentage of the firm owned by the foreign private sector) and 'joint venture of a domestic enterprise' (a dummy variable taking the value 1 if the legal status of the firm is joint venture of a domestic enterprise, and 0 otherwise) to proxy for openness from the perspectives of foreign networks and domestic networks. The results show that 'joint venture of a domestic enterprise' is positively associated with bank financing measured by access to banking finance, but there is no positive relation between bank debt and openness measured by 'foreign participation'.

\subsubsection{Test for non-linear relationship between bribery and loans}


The results of univariate tests in Panel C of Table 2 show that firms pay lower bribes get larger access to bank financing and obtain more bank loans, which reveal there might be a non-linear relationship between bribery and bank loans. Thus, we include bribery squared terms in the regressions. The results show that no matter if the bribery squared term is included, our main results hold.

\subsubsection{Self-selection issue}

The value of ETC might be measured with errors since we do not know for sure if a firm indeed paid bribes. In order to resolve this self-selection bias, we use the bribery measure (whether a gift or informal payment was expected while dealing with bank officials) from the robustness check Section 4.4.1 to instrument the main bribery measure based on ETC in the baseline regression, and then include the instrumental variable in the second-stage regression. The results show that after instrumenting the bribery measure, openness is consistently associated with bank debt.

\subsubsection{Endogeneity issue}

To address the possible endogeneity issue between bribery, firm openness and bank loans, we used the industry-city bribery (openness) averages to instrument individual firm bribes (openness) in the robustness test. Our results are robust after addressing this endogeneity concern.

\section{Conclusions}

Debt financing is the predominant source of external funds for China's corporations, but the Chinese debt market is comprised of an undeveloped corporate bond market and 
dominated by a state-owned banking sector. In this paper, using data from the World Bank covering 1869 private firms in China, we investigate the effects of bribery and firm openness on banks' lending decisions towards private firms in China.

Before considering the effect of firm openness, we find supportive evidence on the role of bribery in helping private firms obtain bank credit, which is consistent with Chen et al. (2013). However, after adding firm openness into our analysis, the significance of bribery disappears. Instead, we find that banks in China prefer to allocate loans to firms with a higher level of openness since higher level of openness is associated with more information disclosure and thus alleviate information asymmetry when banks make lending decisions. After conducting sub-sample tests, this finding is found to hold true only for large firms, manufacturing firms, and firms located in regions with good banking development. This result suggests that firms of these kinds may drive the positive and significant relationship between openness and bank financing.

The finding that bribe payments to bank officials do not help firms as much as openness in obtaining banking finance has at least three important implications. First, given the long tradition of bribery in the Chinese context, bank officials concentrating on screening borrowers for quality rather than asking for bribes reflects the development of China's market environment and the achievement of banking sector reform in China. Second, this finding encourages firms to develop long-term competitive advantages. By way of explanation, if managers come to believe that they can win bank loans more effectively through bribery rather than through improving their operational performance, they will potentially spend more time courting bank officials than focusing on innovation 
activities and making better investment decisions. Such an approach would damage their long-term growth (Wu, 2005). Third, during a transition process from a planned economy to a market economy, private firms in China have the necessity to focus their endeavors on improving openness rather than the traditional ways, which include paying bribes.

We also find private firms with better financial performance, of a larger size, and with more government assistance are more likely to obtain bank loans and loans of a greater size, which are consistent with the findings of Firth et al. (2009). But we do not find consistently supportive evidence on the role of corporate governance of private firms in obtaining bank loans, which supports the findings of Yao et al. (2010). 


\section{References}

Bai, C. E., Hsieh, C. and Qian, Y. 2006. "The return to capital in China”, working paper, NBER.

Barth, J. R., Lin, C., Lin, P. and Song, F. M. 2009. "Corruption in bank lending to firms: Cross-country micro evidence on the beneficial role of competition and information sharing", Journal of Financial Economics, Vol. 91 No. 3, pp. 361-388.

Beck, T., Demirguc-Kunt, A. and Levine, R. 2006. "Bank supervision and corruption in lending", Journal of Monetary Economics, Vol. 53, pp. 2131-2163.

Beck, T., Demirguc-Kunt, A. and Peria, M. S. M. 2007. "Reaching out: Access to and use of banking services across countries", Journal of Financial Economics, Vol. 85 No. 1, pp. 234-266.

Berger, A. and Udell, G. 2002. "Small business credit availability and relationship lending: The importance of bank organisational structure", The Economic Journal, Vol. 112 No. 477, pp. 32-53.

Brandt, L. and Li, H. 2003. "Bank discrimination in transition economies: Ideology, information, or incentives", Journal of Comparative Economics, Vol. 31 No. 3, pp. 387-413.

Cai, H., Fang, H. and Xu, L. C. 2011. "Eat, drink, firms, government: An investigation of corruption from the entertainment and travel costs of Chinese firms", Journal of Law and Economics, Vol. 54, pp. 55-78.

Chen, G. M., Firth, M., Gao, D. and Rui, O. M. 2006. “Ownership structure, corporate governance, and fraud: Evidence from China", Journal of Corporate Finance, Vol. 12 No. 3, pp. 424-448.

Chen, Y., Liu, M. and Su, L. 2013. "Greasing the wheels of bank lending: Evidence from private firms in China”, Journal of Banking and Finance, Vol. 37 No. 7, pp. 2533-2545.

Dinc, I. S. 2005. "Politicians and banks: Political influences on government-owned banks in emerging markets", Journal of Financial Economics, Vol. 77 No. 2, pp. 453-479.

Dong, Y., Liu, Z., Shen, Z. and Sun, Q. 2014. "Political Patronage and Capital Structure in China", Emerging Markets Finance \& Trade, Vol. 50 No. 3, pp. 102-125.

Dopuch, N. and Simunic, D. 1982. "The competition in auditing an assessment", in Fourth Symposium on Auditing Research in Urbana University of Illinois, 1982, pp.401-450.

Economist Intelligence Unit. 2009. Collaboration in China: Paths to profit.

Faccio, M., Masulis, R. and McConnell, J. 2006. "Government bailouts and political connections", Journal of Finance, Vol. 61 No. 6, pp. 2597-2635.

Fan, J., Titman, S. and Twite, G. 2012, “An international comparison of capital structure and debt maturity choices", Journal of Financial and quantitative Analysis, Vol 47 No. 01, pp. 23-56.

Fan, G., Wang, X. and Zhu, H. 2012. NERI Index of Marketization of China's Provinces 2011 Report. Economics Science Press, Beijing (in Chinese).

Firth, M., Lin, C., Liu, P. and Wong, S. M. L. 2009. "Inside the black box: Bank credit allocation in China's private sector", Journal of Banking \& Finance, Vol. 33 No. 6, pp. 1144-1155.

Fontana, R., Geuna, A. and Matt, M. 2003. "Firm size and openness: The driving forces of university-industry collaboration", in Caloghirou, Y., Constantelou, A. and Vonortas, N. S. (Ed.), Knowledge Flows in European Industry, Routledge, London, pp. 185-209.

Fungáčová, Z, Kochanova, A. and Weill, L. 2015. "Does money buy credit? Firm-level evidence on bribery and bank debt”, World Development, Vol. 68, pp. 308-322.

Huang, F. and Rice, J. 2012. "Firm networking and bribery in China: Assessing some potential negative consequences of firm openness", Journal of Business Ethics, Vol. 107 No. 4, pp. 533-545.

Jõeveer, K. 2013. "Firm, country and macroeconomic determinants of capital structure: Evidence from transition economies", Journal of Comparative Economics, Vol. 41 No. 1, pp. 294-308. 
King, M. 1986. "Capital market 'imperfections' and the consumption function", Scandinavian Journal of Economics, Vol. 88 No. 1, pp. 59-80.

Laursen, K. and Salter, A. 2003. "Searching low and high: Why do firms use universities as a source of innovation", paper presented at the 3rd European Meeting on Applied Evolutionary Economics, 10-12 April, Augsburg.

Laursen, K. and Salter, A. 2006. "Open for innovation: The role of openness in explaining innovation performance among UK manufacturing firms", Strategic Management Journal, Vol. 27 No. 2: 131-150.

Li, K., Yue, H. and Zhao, L. 2009. "Ownership, institutions, and capital structure: Evidence from China", Journal of Comparative Economics, Vol. 37 No. 3: 471-490.

Pei, M. 2008. "Fighting corruption: a difficult challenge for Chinese leaders." in Li, C. (Ed.), China's Changing Political Landscape, Brookings Institute, pp. 229-250.

Rajan, R. and Zingales, L. 1998. "Financial dependence and growth", The American Economic Review, Vol. 88 No. 3, pp. 559-596.

Ricci, L. A. and Trionfetti, F. 2012. "Productivity, Networks, and Export Performance: Evidence from a Cross-country Firm Dataset." Review of International Economics, Vol. 20 No. 3, pp. 552-562.

Svensson, J. 2005. "Eight questions about corruption”. Journal of Economic Perspectives, Vol. 19, pp. 19-42.

Stiglitz, J. and Weiss, A. 1981. "Credit rationing in markets with imperfect information", American Economic Review, Vol. 71 No. 3, pp. 393-410.

Weill, L. 2011. "Does corruption hamper bank lending? Macro and micro evidence", Empirical Economics, Vol. 41, pp. 25-42.

$\mathrm{Wu}$, X. 2005. "Corporate governance and corruption: A cross-country analysis", Governance: An International Journal of Policy, Administration, and Institutions, Vol. 18 No. 2, pp. 151-170.

Yao, L. J., Luo, M. and Xia, D. L. 2010. "Corporate governance and bank financing”, Accounting Research, No. 8, pp. 55-61(in Chinese).

Yeung, G. 2009. "How banks in China make lending decisions", Journal of Contemporary China, Vol. 18 No. 59, pp. 285-302.

Zhang, Y. 2009. "Alliance-based network view on Chinese firms catching-up: Case study of Huawei Technologies Co. Ltd.”, working paper, UNUMERIT, 2009. 
Table 1 Descriptive statistics of variables

\begin{tabular}{|c|c|c|c|c|c|c|}
\hline Variables & Obs. & Min & Mean & Median & Max & $\begin{array}{l}\text { Standard } \\
\text { deviation }\end{array}$ \\
\hline Access to banking finance & 1869 & 0 & 0.2151 & 0 & 1 & 0.411 \\
\hline Size of banking finance & 1825 & 0 & 0.048 & 0 & 0.5495 & 0.1224 \\
\hline Openness & 1869 & 0 & 0.4227 & 0 & 3 & 0.7611 \\
\hline Bribery & 1823 & 0 & 0.0242 & 0.0104 & 0.25 & 0.0406 \\
\hline Govt help & 1839 & 0 & 0.1599 & 0 & 1 & 0.3666 \\
\hline Bank competition & 1795 & 0 & 0.7915 & 0.6931 & 3.6889 & 0.6427 \\
\hline Firm size & 1825 & 0.0953 & 9.4427 & 9.3321 & 17.907 & 2.2297 \\
\hline Firm age & 1869 & 1.0986 & 2.2603 & 2.1972 & 3.9703 & 0.7073 \\
\hline ROS & 1844 & -1.8113 & -0.0232 & 0.0219 & 0.4037 & 0.3213 \\
\hline Audit & 1869 & 0 & 0.6704 & 1 & 1 & 0.4702 \\
\hline Manager experience & 1851 & 0 & 1.536 & 1.6094 & 3.4965 & 0.7349 \\
\hline Manager tenure & 1466 & 0 & 1.4753 & 1.3863 & 3.912 & 0.5899 \\
\hline Managerial ownership & 1869 & 0 & 0.3574 & 0 & 1 & 0.4794 \\
\hline Manager wage payment & 1869 & 0 & 0.2039 & 0 & 1 & 0.403 \\
\hline Manager incentive & 1869 & 0 & 0.2755 & 0 & 1 & 0.4469 \\
\hline Duality & 1078 & 0 & 0.4889 & 0 & 1 & 0.5001 \\
\hline Board ownership & 1058 & 0 & 51.7765 & 60 & 100 & 43.1535 \\
\hline Board size & 1073 & 1 & 6.2302 & 5 & 389 & 12.1481 \\
\hline Board independence & 1073 & 0 & 0.1385 & 0 & 1 & 0.24 \\
\hline GDP per capita & 1783 & 9.7146 & 10.3958 & 10.4097 & 11.9944 & 0.5617 \\
\hline City population & 1869 & 4.5677 & 5.5322 & 5.3938 & 6.9068 & 0.6166 \\
\hline Banking sector marketization & 1869 & 1.46 & 4.9627 & 4.53 & 9.23 & 2.3336 \\
\hline
\end{tabular}




\section{Table 2 Univariate test}

Panel A. Univariate test of firms with different levels of openness

\begin{tabular}{|c|c|c|c|c|c|c|c|c|c|c|}
\hline & \multicolumn{2}{|c|}{ Openness_0 } & \multicolumn{2}{|c|}{ Openness_1 } & \multicolumn{2}{|c|}{ Openness_2 } & \multicolumn{2}{|c|}{ Openness_3 } & \multicolumn{2}{|c|}{$\begin{array}{c}\text { Difference tests } \\
\text { (Openness_0-Openness_3) }\end{array}$} \\
\hline & Mean & Median & Mean & Median & Mean & Median & Mean & Median & $t$ value & $z$ value \\
\hline Obs. & \multicolumn{2}{|c|}{1329} & \multicolumn{2}{|c|}{353} & \multicolumn{2}{|c|}{124} & \multicolumn{2}{|c|}{63} & & \\
\hline Access to banking finance & 0.1708 & 0 & 0.2635 & 0 & 0.4435 & 0 & 0.4286 & 0 & $-5.2227 * * *$ & $-5.174 * * *$ \\
\hline Obs. & \multicolumn{2}{|c|}{1292} & \multicolumn{2}{|c|}{349} & \multicolumn{2}{|c|}{122} & \multicolumn{2}{|c|}{62} & & \\
\hline Size of banking finance & 0.0352 & 0 & 0.0566 & 0 & 0.1298 & 0 & 0.1037 & 0 & $-4.9004 * * *$ & $-4.561 * * *$ \\
\hline
\end{tabular}

Panel B. Univariate test of firms without and with bribe payments

\begin{tabular}{|c|c|c|c|c|c|c|}
\hline & \multicolumn{2}{|c|}{ Non-bribery } & \multicolumn{2}{|c|}{ Bribery } & \multicolumn{2}{|c|}{ Difference tests } \\
\hline & Mean & Median & Mean & Median & $t$ value & $z$ value \\
\hline Obs. & \multicolumn{2}{|c|}{168} & \multicolumn{2}{|c|}{1701} & & \\
\hline Access to banking finance & 0.1786 & 0 & 0.2187 & 0 & -1.2073 & -1.207 \\
\hline Obs. & \multicolumn{2}{|c|}{158} & \multicolumn{2}{|c|}{1667} & & \\
\hline Size of banking finance & 0.0330 & 0 & 0.0494 & 0 & $-2.0042 * *$ & -1.193 \\
\hline \multicolumn{7}{|c|}{ Panel C. Univariate test of firms with low and high bribe payments } \\
\hline & \multicolumn{2}{|c|}{ Low-bribery } & \multicolumn{2}{|c|}{ High-bribery } & \multicolumn{2}{|c|}{ Difference tests } \\
\hline & Mean & Median & Mean & Median & $t$ value & $z$ value \\
\hline Obs. & \multicolumn{2}{|c|}{996} & \multicolumn{2}{|c|}{873} & & \\
\hline Access to banking finance & 0.2349 & 0 & 0.1924 & 0 & $2.2328 * *$ & $2.230 * *$ \\
\hline Obs. & \multicolumn{2}{|c|}{977} & \multicolumn{2}{|c|}{848} & & \\
\hline Size of banking finance & 0.0535 & 0 & 0.0415 & 0 & $2.0902 * *$ & $2.306^{* *}$ \\
\hline
\end{tabular}

Note: $*$, **, and $* * *$ denote statistical significance at the $10 \%, 5 \%$, and $1 \%$ level, respectively 
Table 3 The effect of private firms' bribery on bank financing

\begin{tabular}{|c|c|c|c|c|c|c|}
\hline & $\begin{array}{l}\text { Access to } \\
\text { banking } \\
\text { finance }\end{array}$ & $\begin{array}{l}\text { Size of } \\
\text { banking } \\
\text { finance }\end{array}$ & $\begin{array}{c}\text { Access to } \\
\text { banking } \\
\text { finance }\end{array}$ & $\begin{array}{l}\text { Size of } \\
\text { banking } \\
\text { finance }\end{array}$ & $\begin{array}{l}\text { Access to } \\
\text { banking } \\
\text { finance }\end{array}$ & $\begin{array}{l}\text { Size of } \\
\text { banking } \\
\text { finance }\end{array}$ \\
\hline & (1) & (2) & (3) & (4) & (5) & (6) \\
\hline ROS & $\begin{array}{c}0.6030^{* *} \\
(0.2682)\end{array}$ & $\begin{array}{c}0.0252 * * \\
(0.0106)\end{array}$ & $\begin{array}{l}0.6213^{*} \\
(0.3290)\end{array}$ & $\begin{array}{c}0.0267 * * * \\
(0.0078)\end{array}$ & $\begin{array}{l}0.6104 * \\
(0.3378)\end{array}$ & $\begin{array}{c}0.0279 * * * \\
(0.0083)\end{array}$ \\
\hline Bribery & & & & & $\begin{array}{c}0.2661 \\
(3.4590)\end{array}$ & $\begin{array}{c}0.0437 * * \\
(0.0184)\end{array}$ \\
\hline Audit & $\begin{array}{l}-0.0654 \\
(0.1290)\end{array}$ & $\begin{array}{l}-0.0040 \\
(0.0089)\end{array}$ & $\begin{array}{l}0.3903 * \\
(0.2233)\end{array}$ & $\begin{array}{c}0.0099 \\
(0.0091)\end{array}$ & $\begin{array}{l}0.4017^{*} \\
(0.2271)\end{array}$ & $\begin{array}{c}0.0100 \\
(0.0092)\end{array}$ \\
\hline Govt help & $\begin{array}{c}1.1228 * * * \\
(0.1829)\end{array}$ & $\begin{array}{c}0.0554 * * * \\
(0.0107)\end{array}$ & $\begin{array}{c}1.0674 * * * \\
(0.1957)\end{array}$ & $\begin{array}{c}0.0431 * * * \\
(0.0132)\end{array}$ & $\begin{array}{c}1.0577 * * * \\
(0.2018)\end{array}$ & $\begin{array}{c}0.0428 * * * \\
(0.0133)\end{array}$ \\
\hline Bank competition & $\begin{array}{c}0.1539 \\
(0.1300)\end{array}$ & $\begin{array}{c}0.0071 \\
(0.0067)\end{array}$ & $\begin{array}{c}0.1766 \\
(0.2560)\end{array}$ & $\begin{array}{c}0.0041 \\
(0.0094)\end{array}$ & $\begin{array}{c}0.1670 \\
(0.2525)\end{array}$ & $\begin{array}{c}0.0040 \\
(0.0094)\end{array}$ \\
\hline Manager experience & & & $\begin{array}{l}-0.0476 \\
(0.1001)\end{array}$ & $\begin{array}{l}-0.0004 \\
(0.0063)\end{array}$ & $\begin{array}{l}-0.0456 \\
(0.0985)\end{array}$ & $\begin{array}{c}-0.0002 \\
(0.0063)\end{array}$ \\
\hline Manager tenure & & & $\begin{array}{c}0.0965 \\
(0.2075)\end{array}$ & $\begin{array}{l}-0.0033 \\
(0.0099)\end{array}$ & $\begin{array}{c}0.0904 \\
(0.2087)\end{array}$ & $\begin{array}{l}-0.0037 \\
(0.0101)\end{array}$ \\
\hline Managerial ownership & & & $\begin{array}{l}0.5145^{*} \\
(0.2920)\end{array}$ & $\begin{array}{c}0.0084 \\
(0.0130)\end{array}$ & $\begin{array}{l}0.5429^{*} \\
(0.2969)\end{array}$ & $\begin{array}{c}0.0098 \\
(0.0133)\end{array}$ \\
\hline Manager wage payment & & & $\begin{array}{c}0.1554 \\
(0.2342)\end{array}$ & $\begin{array}{c}0.0299 * * \\
(0.0114)\end{array}$ & $\begin{array}{c}0.1532 \\
(0.2491)\end{array}$ & $\begin{array}{c}0.0296^{* *} \\
(0.0122)\end{array}$ \\
\hline Manager incentive & & & $\begin{array}{c}0.1037 \\
(0.1295)\end{array}$ & $\begin{array}{c}0.0000 \\
(0.0116)\end{array}$ & $\begin{array}{c}0.1186 \\
(0.1242)\end{array}$ & $\begin{array}{c}0.0010 \\
(0.0116)\end{array}$ \\
\hline Duality & & & $\begin{array}{l}-0.2304 \\
(0.2147)\end{array}$ & $\begin{array}{l}-0.0018 \\
(0.0107)\end{array}$ & $\begin{array}{l}-0.2137 \\
(0.2261)\end{array}$ & $\begin{array}{c}-0.0008 \\
(0.0110)\end{array}$ \\
\hline Board ownership & & & $\begin{array}{l}0.0061^{*} \\
(0.0031)\end{array}$ & $\begin{array}{c}0.0001 \\
(0.0001)\end{array}$ & $\begin{array}{l}0.0060^{*} \\
(0.0032)\end{array}$ & $\begin{array}{c}0.0001 \\
(0.0001)\end{array}$ \\
\hline Board size & & & $\begin{array}{c}0.0248 \\
(0.0335)\end{array}$ & $\begin{array}{c}0.0009 \\
(0.0018)\end{array}$ & $\begin{array}{c}0.0251 \\
(0.0345)\end{array}$ & $\begin{array}{c}0.0008 \\
(0.0019)\end{array}$ \\
\hline Board independence & & & $\begin{array}{c}0.2131 \\
(0.3528)\end{array}$ & $\begin{array}{c}0.0288 \\
(0.0222)\end{array}$ & $\begin{array}{c}0.2604 \\
(0.3441)\end{array}$ & $\begin{array}{c}0.0325 \\
(0.0227)\end{array}$ \\
\hline Firm size & $\begin{array}{c}0.3412 * * * \\
(0.0655)\end{array}$ & $\begin{array}{c}0.0083 * * \\
(0.0029)\end{array}$ & $\begin{array}{c}0.4440 * * * \\
(0.0550)\end{array}$ & $\begin{array}{c}0.0114 * * * \\
(0.0024)\end{array}$ & $\begin{array}{c}0.4444 * * * \\
(0.0512)\end{array}$ & $\begin{array}{c}0.0116 * * * \\
(0.0023)\end{array}$ \\
\hline Firm age & $\begin{array}{l}-0.0316 \\
(0.0818)\end{array}$ & $\begin{array}{c}0.0016 \\
(0.0041)\end{array}$ & $\begin{array}{c}-0.2244 * \\
(0.1215)\end{array}$ & $\begin{array}{l}-0.0034 \\
(0.0076)\end{array}$ & $\begin{array}{l}-0.2231 * \\
(0.1156)\end{array}$ & $\begin{array}{l}-0.0029 \\
(0.0072)\end{array}$ \\
\hline GDP per capita & $\begin{array}{c}-0.5462 * * \\
(0.2208)\end{array}$ & $\begin{array}{c}-0.0196 * * \\
(0.0078)\end{array}$ & $\begin{array}{c}-0.4560^{*} \\
(0.2758)\end{array}$ & $\begin{array}{l}-0.0112 \\
(0.0118)\end{array}$ & $\begin{array}{l}-0.4369 \\
(0.2744)\end{array}$ & $\begin{array}{l}-0.0094 \\
(0.0114)\end{array}$ \\
\hline City population & $\begin{array}{c}-0.6019 * * \\
(0.1642)\end{array}$ & $\begin{array}{c}-0.0218 * * \\
(0.0053)\end{array}$ & $\begin{array}{l}-0.4511 \\
(0.2989)\end{array}$ & $\begin{array}{l}-0.0093 \\
(0.0110)\end{array}$ & $\begin{array}{l}-0.4475 \\
(0.2994)\end{array}$ & $\begin{array}{l}-0.0088 \\
(0.0111)\end{array}$ \\
\hline $\begin{array}{l}\text { Banking sector } \\
\text { marketization }\end{array}$ & $\begin{array}{c}0.1385^{* * *} * \\
(0.0398)\end{array}$ & $\begin{array}{c}0.0053^{* * * *} \\
(0.0015)\end{array}$ & $\begin{array}{c}0.0881 \\
(0.0816)\end{array}$ & $\begin{array}{l}0.0051^{*} \\
(0.0025)\end{array}$ & $\begin{array}{c}0.0868 \\
(0.0812)\end{array}$ & $\begin{array}{l}0.0049^{*} \\
(0.0025)\end{array}$ \\
\hline Industry dummies & Yes & Yes & Yes & Yes & Yes & Yes \\
\hline Constant & $\begin{array}{c}3.6979 \\
(2.8779)\end{array}$ & $\begin{array}{c}0.2694 * * \\
(0.0975)\end{array}$ & $\begin{array}{c}0.1410 \\
(4.0773)\end{array}$ & $\begin{array}{c}0.0608 \\
(0.1354)\end{array}$ & $\begin{array}{c}-0.0985 \\
(4.0707)\end{array}$ & $\begin{array}{c}0.0347 \\
(0.1324)\end{array}$ \\
\hline Observations & 1600 & 1629 & 800 & 806 & 794 & 799 \\
\hline $\begin{array}{l}\text { Adjusted } \\
\text { R-squared/Pseudo R2 }\end{array}$ & 0.1912 & 0.1017 & 0.2421 & 0.1303 & 0.2426 & 0.1304 \\
\hline
\end{tabular}

Notes: Robust standard errors, which are clustered by city, are in parentheses. *, **, and *** denote statistical significance at the $10 \%, 5 \%$, and $1 \%$ level, respectively. 
Table 4 The effect of private firms' openness and bribery on bank financing

\begin{tabular}{|c|c|c|}
\hline & Access to banking finance & Size of banking finance \\
\hline & (1) & (2) \\
\hline \multirow[t]{2}{*}{ ROS } & 0.5073 & $0.0221 * *$ \\
\hline & $(0.3610)$ & $(0.0106)$ \\
\hline \multirow[t]{2}{*}{ Bribery } & -2.7854 & -0.0091 \\
\hline & $(5.0580)$ & $(0.1464)$ \\
\hline \multirow[t]{2}{*}{ Openness } & $0.2240 *$ & $0.0219 * * *$ \\
\hline & $(0.1351)$ & $(0.0068)$ \\
\hline \multirow[t]{2}{*}{ Bribery $\times$ Openness } & 2.1814 & 0.0183 \\
\hline & $(3.7377)$ & $(0.2084)$ \\
\hline \multirow[t]{2}{*}{ Audit } & $0.4181 * *$ & 0.0110 \\
\hline & $(0.2118)$ & $(0.0087)$ \\
\hline \multirow[t]{2}{*}{ Govt help } & $0.9800 * * *$ & $0.0361 * * *$ \\
\hline & $(0.1911)$ & $(0.0118)$ \\
\hline \multirow[t]{2}{*}{ Bank competition } & 0.1648 & 0.0024 \\
\hline & $(0.2620)$ & $(0.0098)$ \\
\hline \multirow[t]{2}{*}{ Firm size } & $0.4329 * * *$ & $0.0102 * * *$ \\
\hline & $(0.0516)$ & $(0.0021)$ \\
\hline \multirow[t]{2}{*}{ Firm age } & $-0.2617 * *$ & -0.0045 \\
\hline & $(0.1188)$ & $(0.0071)$ \\
\hline \multirow[t]{2}{*}{ GDP per capita } & -0.4123 & -0.0067 \\
\hline & $(0.2663)$ & $(0.0104)$ \\
\hline \multirow[t]{2}{*}{ City population } & $-0.4700^{*}$ & -0.0092 \\
\hline & $(0.2787)$ & $(0.0099)$ \\
\hline \multirow[t]{2}{*}{ Banking sector marketization } & 0.0878 & $0.0050 * *$ \\
\hline & $(0.0777)$ & $(0.0023)$ \\
\hline Industry dummies & Yes & Yes \\
\hline \multirow[t]{2}{*}{ Constant } & -0.0289 & 0.0264 \\
\hline & $(3.9635)$ & $(0.1221)$ \\
\hline Observations & 794 & 799 \\
\hline Adjusted R-squared/Pseudo $\mathrm{R}^{2}$ & 0.2497 & 0.1458 \\
\hline
\end{tabular}

Notes: Robust standard errors, which are clustered by city, are in parentheses. *, **, and *** denote statistical significance at the $10 \%, 5 \%$, and $1 \%$ level, respectively. To reduce the space taken for tables, we only report the important coefficients in this table. 
Table 5 Sub-sample analysis based on firm size

\begin{tabular}{|c|c|c|c|c|}
\hline & \multicolumn{2}{|c|}{ Small firm } & \multicolumn{2}{|c|}{ Large firm } \\
\hline & $\begin{array}{c}\text { Access to } \\
\text { banking finance }\end{array}$ & $\begin{array}{l}\text { Size of banking } \\
\text { finance }\end{array}$ & $\begin{array}{c}\text { Access to } \\
\text { banking finance }\end{array}$ & $\begin{array}{l}\text { Size of banking } \\
\text { finance }\end{array}$ \\
\hline & (1) & (2) & (3) & (4) \\
\hline \multirow[t]{2}{*}{ ROS } & 1.0893 & 0.0231 & 0.5652 & 0.0216 \\
\hline & $(0.8702)$ & $(0.0196)$ & $(0.4742)$ & $(0.0216)$ \\
\hline \multirow[t]{2}{*}{ Bribery } & 2.3728 & -0.0763 & -4.5377 & 0.0148 \\
\hline & $(10.6047)$ & $(0.1053)$ & $(6.7669)$ & $(0.3816)$ \\
\hline \multirow[t]{2}{*}{ Openness } & 0.4401 & -0.0025 & $0.2666^{*}$ & $0.0310 * * *$ \\
\hline & $(0.4840)$ & $(0.0112)$ & $(0.1404)$ & $(0.0094)$ \\
\hline \multirow[t]{2}{*}{ Bribery $\times$ Openness } & 4.6808 & 0.1856 & -2.0917 & -0.2353 \\
\hline & $(7.5861)$ & $(0.2319)$ & $(4.4293)$ & $(0.2519)$ \\
\hline \multirow[t]{2}{*}{ Audit } & $1.1711 * *$ & $0.0183^{* *}$ & 0.3113 & 0.0062 \\
\hline & $(0.5163)$ & $(0.0083)$ & $(0.3821)$ & $(0.0198)$ \\
\hline \multirow[t]{2}{*}{ Govt help } & $2.9618 * *$ & 0.0414 & $0.7925 * * *$ & $0.0355^{*}$ \\
\hline & $(1.4308)$ & $(0.0414)$ & $(0.2465)$ & $(0.0185)$ \\
\hline \multirow[t]{2}{*}{ Bank competition } & 0.0150 & -0.0075 & 0.1213 & 0.0016 \\
\hline & $(0.5478)$ & $(0.0103)$ & $(0.2758)$ & $(0.0121)$ \\
\hline \multirow[t]{2}{*}{ Firm size } & $1.1213 * * *$ & 0.0044 & $0.4086^{* * *}$ & $0.0142 *$ \\
\hline & $(0.3768)$ & $(0.0044)$ & $(0.1066)$ & $(0.0073)$ \\
\hline \multirow[t]{2}{*}{ Firm age } & $-1.5412 * *$ & -0.0114 & -0.1346 & -0.0029 \\
\hline & $(0.6005)$ & $(0.0082)$ & $(0.1013)$ & $(0.0092)$ \\
\hline \multirow[t]{2}{*}{ GDP per capita } & -0.1355 & 0.0066 & -0.3798 & -0.0075 \\
\hline & $(0.4409)$ & $(0.0081)$ & $(0.3017)$ & $(0.0106)$ \\
\hline \multirow[t]{2}{*}{ City population } & $-0.8729 *$ & 0.0046 & -0.2792 & -0.0066 \\
\hline & $(0.5262)$ & $(0.0083)$ & $(0.2862)$ & $(0.0119)$ \\
\hline \multirow[t]{2}{*}{ Banking sector marketization } & 0.0722 & 0.0005 & 0.0865 & $0.0059 *$ \\
\hline & $(0.1643)$ & $(0.0029)$ & $(0.0950)$ & $(0.0030)$ \\
\hline Industry dummies & Yes & Yes & Yes & Yes \\
\hline \multirow[t]{2}{*}{ Constant } & -4.4396 & -0.0796 & -1.6358 & -0.0647 \\
\hline & $(6.1897)$ & $(0.0940)$ & $(4.7086)$ & $(0.1578)$ \\
\hline Observations & 241 & 299 & 498 & 500 \\
\hline Adjusted R-squared/Pseudo $\mathrm{R}^{2}$ & 0.3456 & 0.0315 & 0.1767 & 0.1341 \\
\hline
\end{tabular}

Notes: Robust standard errors, which are clustered by city, are in parentheses. *, **, and *** denote statistical significance at the $10 \%, 5 \%$, and $1 \%$ level, respectively. To reduce the space taken for tables, we only report the important coefficients in this table. 
Table 6 Sub-sample analysis based on industry

\begin{tabular}{|c|c|c|c|c|}
\hline & \multicolumn{2}{|c|}{ Manufacturing } & \multicolumn{2}{|c|}{ Service } \\
\hline & $\begin{array}{c}\text { Access to } \\
\text { banking finance }\end{array}$ & $\begin{array}{c}\text { Size of banking } \\
\text { finance }\end{array}$ & $\begin{array}{c}\text { Access to } \\
\text { banking finance }\end{array}$ & $\begin{array}{c}\text { Size of banking } \\
\text { finance }\end{array}$ \\
\hline & (1) & (2) & (3) & (4) \\
\hline ROS & $\begin{array}{c}0.4737 \\
(0.3723)\end{array}$ & $\begin{array}{c}0.0305 * * \\
(0.0134)\end{array}$ & $\begin{array}{c}-0.7026 \\
(1.6341)\end{array}$ & $\begin{array}{c}0.0039 \\
(0.0074)\end{array}$ \\
\hline Bribery & $\begin{array}{l}-3.6897 \\
(5.5903)\end{array}$ & $\begin{array}{l}-0.0756 \\
(0.2206)\end{array}$ & $\begin{array}{c}-5.0535 \\
(15.2651)\end{array}$ & $\begin{array}{c}0.0420 \\
(0.0500)\end{array}$ \\
\hline Openness & $\begin{array}{c}0.2168 \\
(0.1444)\end{array}$ & $\begin{array}{c}0.0217 * * \\
(0.0097)\end{array}$ & $\begin{array}{c}0.5596 \\
(0.5517)\end{array}$ & $\begin{array}{c}0.0110 \\
(0.0126)\end{array}$ \\
\hline Bribery $\times$ Openness & $\begin{array}{c}2.7720 \\
(3.9024)\end{array}$ & $\begin{array}{c}0.0692 \\
(0.2406)\end{array}$ & $\begin{array}{c}5.2957 \\
(14.3057)\end{array}$ & $\begin{array}{l}-0.0625 \\
(0.0932)\end{array}$ \\
\hline Audit & $\begin{array}{l}0.3771^{*} \\
(0.2217)\end{array}$ & $\begin{array}{c}0.0107 \\
(0.0103)\end{array}$ & $\begin{array}{l}2.8783 * * \\
(1.4102)\end{array}$ & $\begin{array}{c}0.0073 \\
(0.0056)\end{array}$ \\
\hline Govt help & $\begin{array}{c}0.9602 * * * \\
(0.2362)\end{array}$ & $\begin{array}{r}0.0307 * * \\
(0.0118)\end{array}$ & $\begin{array}{l}4.0361 * * \\
(1.9405)\end{array}$ & $\begin{array}{l}0.0881 * * \\
(0.0318)\end{array}$ \\
\hline Bank competition & $\begin{array}{c}0.1731 \\
(0.2528)\end{array}$ & $\begin{array}{c}0.0040 \\
(0.0106)\end{array}$ & $\begin{array}{c}1.0085 \\
(1.0620)\end{array}$ & $\begin{array}{c}0.0015 \\
(0.0090)\end{array}$ \\
\hline Firm size & $\begin{array}{c}0.4462 * * * \\
(0.0483)\end{array}$ & $\begin{array}{c}0.0126 * * * \\
(0.0026)\end{array}$ & $\begin{array}{c}0.1297 \\
(0.2193)\end{array}$ & $\begin{array}{c}0.0026 \\
(0.0020)\end{array}$ \\
\hline Firm age & $\begin{array}{c}-0.2845 * * * \\
(0.1085)\end{array}$ & $\begin{array}{l}-0.0048 \\
(0.0076)\end{array}$ & $\begin{array}{l}-1.0054 \\
(1.1351)\end{array}$ & $\begin{array}{l}-0.0077 \\
(0.0085)\end{array}$ \\
\hline GDP per capita & $\begin{array}{l}-0.4869^{*} \\
(0.2515)\end{array}$ & $\begin{array}{l}-0.0093 \\
(0.0134)\end{array}$ & $\begin{array}{l}1.2023 \\
(1.7281)\end{array}$ & $\begin{array}{c}0.0073 \\
(0.0096)\end{array}$ \\
\hline City population & $\begin{array}{c}-0.6148 * * * \\
(0.2347)\end{array}$ & $\begin{array}{l}-0.0130 \\
(0.0115)\end{array}$ & $\begin{array}{c}2.3132 \\
(1.8423)\end{array}$ & $\begin{array}{c}0.0085 \\
(0.0071)\end{array}$ \\
\hline Banking sector marketization & $\begin{array}{c}0.0869 \\
(0.0711)\end{array}$ & $\begin{array}{l}0.0052^{*} \\
(0.0029)\end{array}$ & $\begin{array}{c}0.0909 \\
(0.1731)\end{array}$ & $\begin{array}{c}0.0026 \\
(0.0017)\end{array}$ \\
\hline Industry dummies & Yes & Yes & Yes & Yes \\
\hline Constant & $\begin{array}{c}1.7618 \\
(3.4670)\end{array}$ & $\begin{array}{c}0.0477 \\
(0.1486)\end{array}$ & $\begin{array}{l}-36.1507 \\
(26.7025)\end{array}$ & $\begin{array}{l}-0.1471 \\
(0.1377)\end{array}$ \\
\hline Observations & 642 & 647 & 152 & 152 \\
\hline Adjusted R-squared/Pseudo $\mathrm{R}^{2}$ & 0.5194 & 0.1182 & 0.2104 & 0.2158 \\
\hline
\end{tabular}

Notes: Robust standard errors, which are clustered by city, are in parentheses. *, **, and *** denote statistical significance at the $10 \%, 5 \%$, and $1 \%$ level, respectively. To reduce the space taken for tables, we only report the important coefficients in this table. 
Table 7 Sub-sample analysis based on the development of local banking sector

\begin{tabular}{|c|c|c|c|c|}
\hline & \multicolumn{2}{|c|}{ Poor banking development } & \multicolumn{2}{|c|}{ Good banking development } \\
\hline & $\begin{array}{c}\text { Access to } \\
\text { banking finance }\end{array}$ & $\begin{array}{c}\text { Size of banking } \\
\text { finance }\end{array}$ & $\begin{array}{c}\text { Access to } \\
\text { banking finance }\end{array}$ & $\begin{array}{l}\text { Size of banking } \\
\text { finance }\end{array}$ \\
\hline & (1) & $(2)$ & (3) & (4) \\
\hline ROS & $\begin{array}{c}1.4174 * * \\
(0.6716)\end{array}$ & $\begin{array}{c}0.0217 \\
(0.0172)\end{array}$ & $\begin{array}{c}0.2657 \\
(0.4245)\end{array}$ & $\begin{array}{c}0.0241 \\
(0.0152)\end{array}$ \\
\hline Bribery & $\begin{array}{c}-11.8683 * * * \\
(3.8524)\end{array}$ & $\begin{array}{l}-0.2268 \\
(0.1720)\end{array}$ & $\begin{array}{l}-0.0747 \\
(7.0690)\end{array}$ & $\begin{array}{c}0.1983 \\
(0.2351)\end{array}$ \\
\hline Openness & $\begin{array}{l}-0.1618 \\
(0.2331)\end{array}$ & $\begin{array}{c}0.0060 \\
(0.0135)\end{array}$ & $\begin{array}{c}0.4913 * * * \\
(0.1488)\end{array}$ & $\begin{array}{c}0.0376 * * * \\
(0.0091)\end{array}$ \\
\hline Bribery $\times$ Openness & $\begin{array}{c}13.7113 * * \\
(6.0463)\end{array}$ & $\begin{array}{c}0.3356 \\
(0.3459)\end{array}$ & $\begin{array}{c}-5.8779 * * \\
(2.9153)\end{array}$ & $\begin{array}{c}-0.3262 * * * \\
(0.0886)\end{array}$ \\
\hline Audit & $\begin{array}{c}0.2065 \\
(0.3173)\end{array}$ & $\begin{array}{c}0.0090 \\
(0.0120)\end{array}$ & $\begin{array}{c}0.2858 \\
(0.2722)\end{array}$ & $\begin{array}{c}0.0043 \\
(0.0124)\end{array}$ \\
\hline Govt help & $\begin{array}{c}1.4587 * * * \\
(0.3300)\end{array}$ & $\begin{array}{c}0.0436 * * * \\
(0.0120)\end{array}$ & $\begin{array}{c}1.0469 * * * \\
(0.3512)\end{array}$ & $\begin{array}{c}0.0314 \\
(0.0220)\end{array}$ \\
\hline Bank competition & $\begin{array}{c}0.5431 \\
(0.5250)\end{array}$ & $\begin{array}{c}0.0108 \\
(0.0127)\end{array}$ & $\begin{array}{l}-0.0721 \\
(0.3257)\end{array}$ & $\begin{array}{l}-0.0026 \\
(0.0136)\end{array}$ \\
\hline Firm size & $\begin{array}{c}0.5681 * * * \\
(0.0890)\end{array}$ & $\begin{array}{c}0.0069 * * \\
(0.0027)\end{array}$ & $\begin{array}{c}0.4166 * * * \\
(0.0860)\end{array}$ & $\begin{array}{c}0.0154 * * * \\
(0.0039)\end{array}$ \\
\hline Firm age & $\begin{array}{l}-0.3082 \\
(0.3293)\end{array}$ & $\begin{array}{c}0.0038 \\
(0.0152)\end{array}$ & $\begin{array}{c}-0.2734 * * \\
(0.1307)\end{array}$ & $\begin{array}{l}-0.0140 * \\
(0.0065)\end{array}$ \\
\hline GDP per capita & $\begin{array}{c}-1.4088 * * * \\
(0.4724)\end{array}$ & $\begin{array}{l}-0.0208 \\
(0.0147)\end{array}$ & $\begin{array}{l}-0.0640 \\
(0.2819)\end{array}$ & $\begin{array}{l}-0.0097 \\
(0.0104)\end{array}$ \\
\hline City population & $\begin{array}{c}-1.0522 * * * \\
(0.2850)\end{array}$ & $\begin{array}{l}-0.0251 * \\
(0.0109)\end{array}$ & $\begin{array}{l}-0.0560 \\
(0.2743)\end{array}$ & $\begin{array}{l}-0.0075 \\
(0.0084)\end{array}$ \\
\hline Banking sector marketization & $\begin{array}{c}-1.0943 * * * \\
(0.2500)\end{array}$ & $\begin{array}{c}-0.0144 * * * \\
(0.0032)\end{array}$ & $\begin{array}{c}0.0009 \\
(0.1016)\end{array}$ & $\begin{array}{l}0.0080 * \\
(0.0038)\end{array}$ \\
\hline Industry dummies & Yes & Yes & Yes & Yes \\
\hline Constant & $\begin{array}{c}16.1338 * * \\
(6.6376)\end{array}$ & $\begin{array}{l}0.3257 * \\
(0.1626)\end{array}$ & $\begin{array}{l}-5.3947 \\
(4.5599)\end{array}$ & $\begin{array}{c}0.0117 \\
(0.1521)\end{array}$ \\
\hline Observations & 358 & 363 & 404 & 436 \\
\hline Adjusted R-squared/Pseudo $\mathrm{R}^{2}$ & 0.3714 & 0.1294 & 0.2232 & 0.1836 \\
\hline
\end{tabular}

Notes: Robust standard errors, which are clustered by city, are in parentheses. *, **, and *** denote statistical significance at the $10 \%, 5 \%$, and $1 \%$ level, respectively. To reduce the space taken for tables, we only report the important coefficients in this table. 